\title{
Murdannia saddlepeakensis (Commelinaceae) - a new species from Andaman and Nicobar Islands, India
}

\author{
M. Venkat Ramana', Mayur Nandikar², R. V. Gurav², \\ Johny Kumar Tagore', M. Sanjappa ${ }^{3}$
}

I Botanical Survey of India, Andaman and Nicobar Regional Centre, Haddo, Port Blair-744 102, Andaman and Nicobar Islands, India 2 Department of Botany, Shivaji University, Kolhapur 3 Former Director, Botanical Survey of India, Kolkata, India

Corresponding author: Mayur Nandikar (mnandikar@gmail.com)

Academic editor: W. J. Kress | Received 30 June 2012 | Accepted 16 January 2013 | Published 8 February 2013

Citation: Ramana MV, Nandikar M, Gurav RV, Tagore JK, Sanjappa M (2013) Murdannia saddlepeakensis (Commelinaceae) - a new species from Andaman and Nicobar Islands, India. PhytoKeys 20: 9-15. doi: 10.3897/ phytokeys.20.3611

\begin{abstract}
Murdannia saddlepeakensis (Commelinaceae), a new species from the Andaman and Nicobar Islands, India, is described and illustrated. The new species is remarkable for its narrowly linear leaves, two fertile stamens, single seeded locule and scorbiculate seeds.
\end{abstract}

\section{Keywords}

Commelinaceae, Murdannia saddlepeakensis, new species, Andaman and Nicobar Islands, India

\section{Introduction}

The genus Murdannia is represented by 54 species (Govaerts and Faden 2004), of which 27 taxa are reported from India (modified after Karthikeyan et al. 1989). Three new taxa viz., M. fadeniana Nampy \& Joby (Nampy and Joby 2003), M. satheeshiana Joby et al. (Joby et al. 2011) and M. brownii Nandikar \& Gurav (Nandikar and Gurav 2011) have been described during the last decade. In addition, M. striatipetala Faden has been rediscovered from India (Nandikar et al. 2011). The Western Ghats of India 
alone comprises twenty-two species and serve as a major centre of diversification for Murdannia.

The Andaman and Nicobar Islands harbour luxuriant lowland rainforests besides wetlands, mangroves and coral reefs. The floral elements of these Islands often show close affinity with that of Indonesia, Malaysia, Myanmar, Thailand and Sri Lanka. Saddle Peak National Park which is located in the North Andaman Islands harbours unique stunted evergreen vegetation that is found only in restricted localities of the Andaman Islands (Rao 1986).

During a recent botanical excursion, we came across an interesting specimen of Murdannia in an open scrub forest of Saddle Peak National Park. The specimens were collected and critically studied. It was found that the specimens did not match any of the known species of the genus and hence have been described and illustrated here as a novelty. In addition, a key for Murdannia species of Andaman and Nicobar Islands and some other species similar to M. saddlepeakensis has been provided to facilitate identification.

\section{Taxonomic treatment}

\section{Murdannia saddlepeakensis M.V.Ramana \& Nandikar, sp. nov.} urn:Isid:ipni.org:names:77124862-1

http://species-id.net/wiki/Murdannia_saddlepeakensis

Figs 1,2

Type. India. North Andaman: Saddle Peak National Park, open scrub forests (Fig.1A), $13^{\circ} 09^{\prime} \mathrm{N}, 93^{\circ} 01^{\prime} \mathrm{E}$, at $508 \mathrm{~m}, 18$ November 2011, M.V.Ramana 0550 (holotype: CAL; isotypes: US, BSI, SUK, PBL).

Description. Erect, 40-60 cm high, glabrous perennial with a basal rosette of leaves (Fig.1-B); roots fibrous, 2-4 cm long and $2 \mathrm{~mm}$ in diam. Leaves rosette, sheaths $0.5-1 \mathrm{~cm}$ long, lamina narrowly linear, $20-60 \mathrm{~cm}$ long, $0.4-0.8 \mathrm{~cm}$ wide, apex acuminate, base rounded merged into the sheath, margins entire; cauline leaves with sheaths $0.2-2 \mathrm{~cm}$ long, glabrous, narrowly lanceolate to linear, $1-25 \mathrm{~cm}$ long, $0.2-0.5 \mathrm{~mm}$ wide, base rounded, apex acute to acuminate, glabrous, margin entire, often scabrid; flowering shoot terminal in the basal rosette, erect, $20-40 \mathrm{~cm}$ long, unbranched or rarely branched from apically reduced cauline leaves (a bract). Inflorescence terminal and axillary (from uppermost foliaceous bract) of peduncled cincinni (Fig. 2-B); peduncles 2-7 cm long, glabrous, cincinni to $2 \mathrm{~cm}$ long, few flowered, bracteoles $5 \mathrm{~mm}$ long, caducous. Flowers bisexual (Fig. 1-C; Fig. 2-C,D), c. $1.5 \mathrm{~cm}$ wide, opening 1230-1600 hr; pedicels (2-) 3-5 mm long (not declinate in capsule); sepals elliptic to oblong elliptic, 5-6 mm long, pale white to green; petals ovate to obovate, lilac to pale lavender; stamens 2 (Fig. 2E), filaments densely bearded, (3-) $4 \mathrm{~mm}$ long, anthers elliptic, c. $1 \mathrm{~mm}$ long; staminodes 3 (Fig. 2G), antepetalous with glabrous to sparsely bearded filaments, antherodes tri-lobed, yellow; one rudimentary stamen, antisepalous 

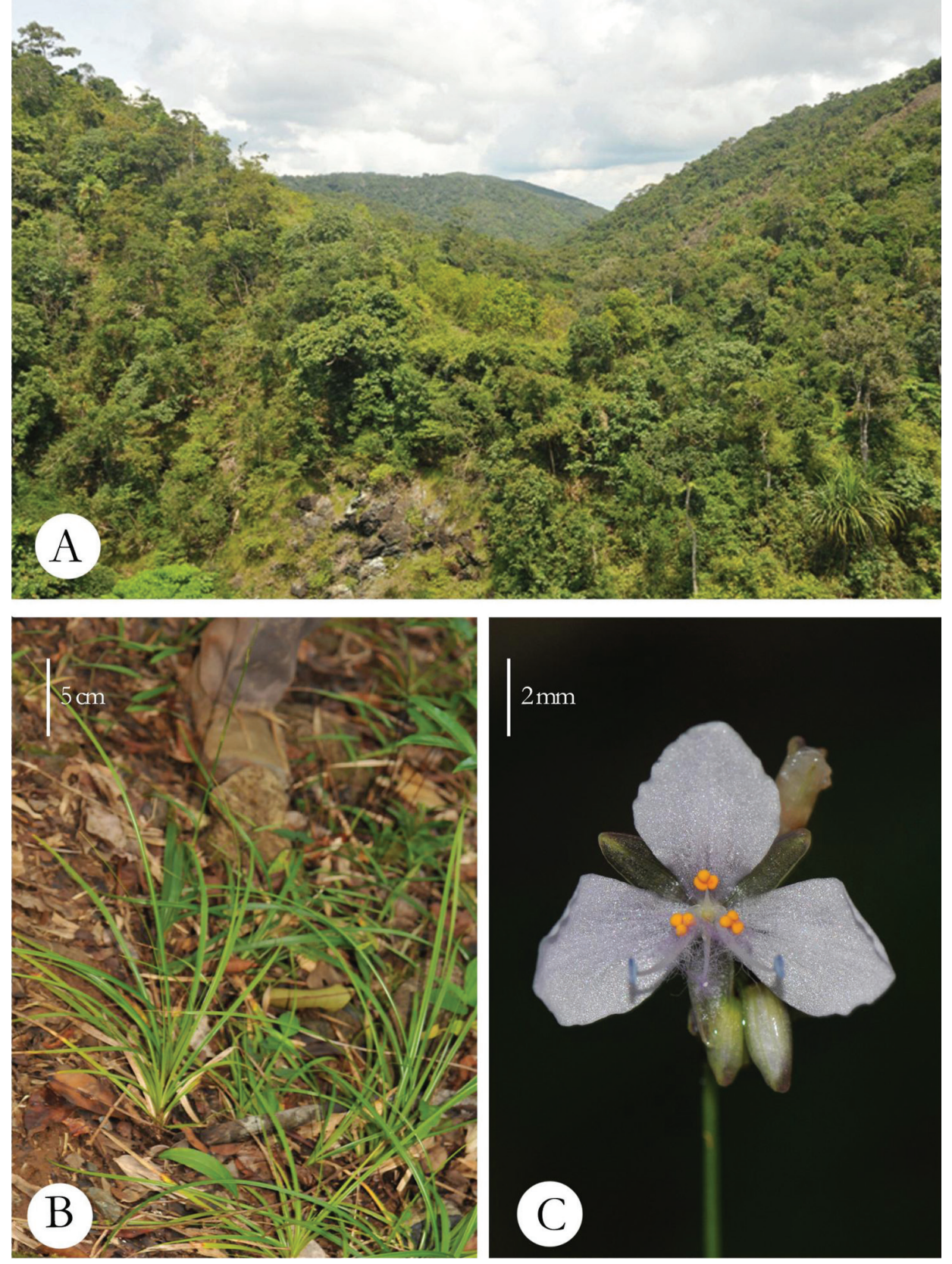

Figure I. Murdannia saddlepeakensis A Habitat (a view of Saddle Peak National Park) B Habit C Flower, ventral view.

(Fig. 2F) with densely bearded filament ending with sterile knob; ovary glabrous; style recurved towards staminodes, (3-)4 mm long; stigma simple. Capsule subglobose, 4-5 mm long, $3 \mathrm{~mm}$ wide, locules 1-seeded. Seeds (Fig. 2J, K) elliptic or rarely ovoid, 
2.5-5 mm long, 1.5-3 mm wide, testa scorbiculate on all surfaces, the depressions often partially uniting on the dorsal surface, forming a little larger, irregular depressions, dark brown, hilum linear or oblong-linear, embryotega dorsal-semidorsal, farinose sparsely in all depressions and around the embryotega.

Distribution. Murdannia saddlepeakensis is so far only known from Saddle Peak National Park, North Andaman Islands, India.

Ecology. It grows in an open scrub forest in rocky situations at an elevation of $508 \mathrm{~m}$. The common associates are Sonerila andamanensis Stapf \& King (Melastomataceae), Ophiorrhiza mungos L. (Rubiaceae) and Gomphostemma javanicum (Blume) Benth. (Lamiaceae). It was observed flowering and fruiting from October to February.

Etymology. Murdannia saddlepeakensis is named after the type locality Saddle Peak National Park. It is the highest peak of the entire archipelago, reaching an altitude of $732 \mathrm{~m}$.

Conservation status. Murdannia saddlepeakensis was collected only once from the Saddle Peak National Park (North Andaman Islands). At this site c. 25 individuals in an open scrub forest in rocky situations were observed and hence it is assumed to be rare. However, larger part of the National Park is unexplored due to human inaccessibility. Therefore, the species can be accessed as "Data Deficient" (DD), using the criteria of IUCN (2001).

Discussion. Murdannia saddlepeakensis belongs to the group Terminatae G. Brückn. (173: 1830) [Inflorescence terminal, many-flowered, the main shoot and lateral flowering shoots few to several, shortened, completely tufted]. In India, series Terminatae is represented by eight species viz. $M$. dimorpha G. Brückn., M. divergens (C.B. Clarke) G. Brückn., M. hookeri (C.B. Clarke) G. Brückn., M. japonica (Thunb.) Faden, M. gigantea (Vahl) G. Brückn., M. loriformis (Hassk.) R.S. Rao \& Kammathy, M. nudiflora (L.) Brenan and M. simplex (Vahl) Brenan (modified after Brückn. 1930). The first four species have more than two seeds per locule and rest four have two seeds per locule while $M$. saddlepeakensis has single seed per locule.

Murdannia saddlepeakensis closely resembles $M$. simplex but can be easily distinguished by its narrow linear leaves, terminal flowering shoot in the basal rosette, glabrous leaf sheaths, single seeded locule, elliptic seed with scorbiculate surface. In addition, M. saddlepeakensis is restricted to northern Andaman Island whereas M. simplex is much more wide spread in Tropical Africa and Asia. M. gigantea with a terminal flowering shoot also is similar to M. saddlepeakensis but differs in having thick, fibrous roots, broad leaves, three stamens and seeds with dorsal embryotega. M. saddlepeakensis can also be mistaken for the widespread M. loriformis in general. However, the presence of erect, terminal flowering shoot and scorbiculate, single seeded locule along with anthesis by noon supports its distinctness.

Pandey and Diwakar (2008) recorded five species of Murdannia from Andaman \& Nicobar Islands namely Murdannia crocea (Griff.) Faden subsp. crocea, M. gigantea (Vahl) G. Brückn., M. nudiflora (L.) Brenan, M. spirata (L.) G.Brückn. and M. vaginata (L.) G.Brückn. The occurrence of Murdannia crocea (Griff.) Faden subsp. crocea from Andaman seems to be erroneous as the screening of herbarium specimens at Kew 


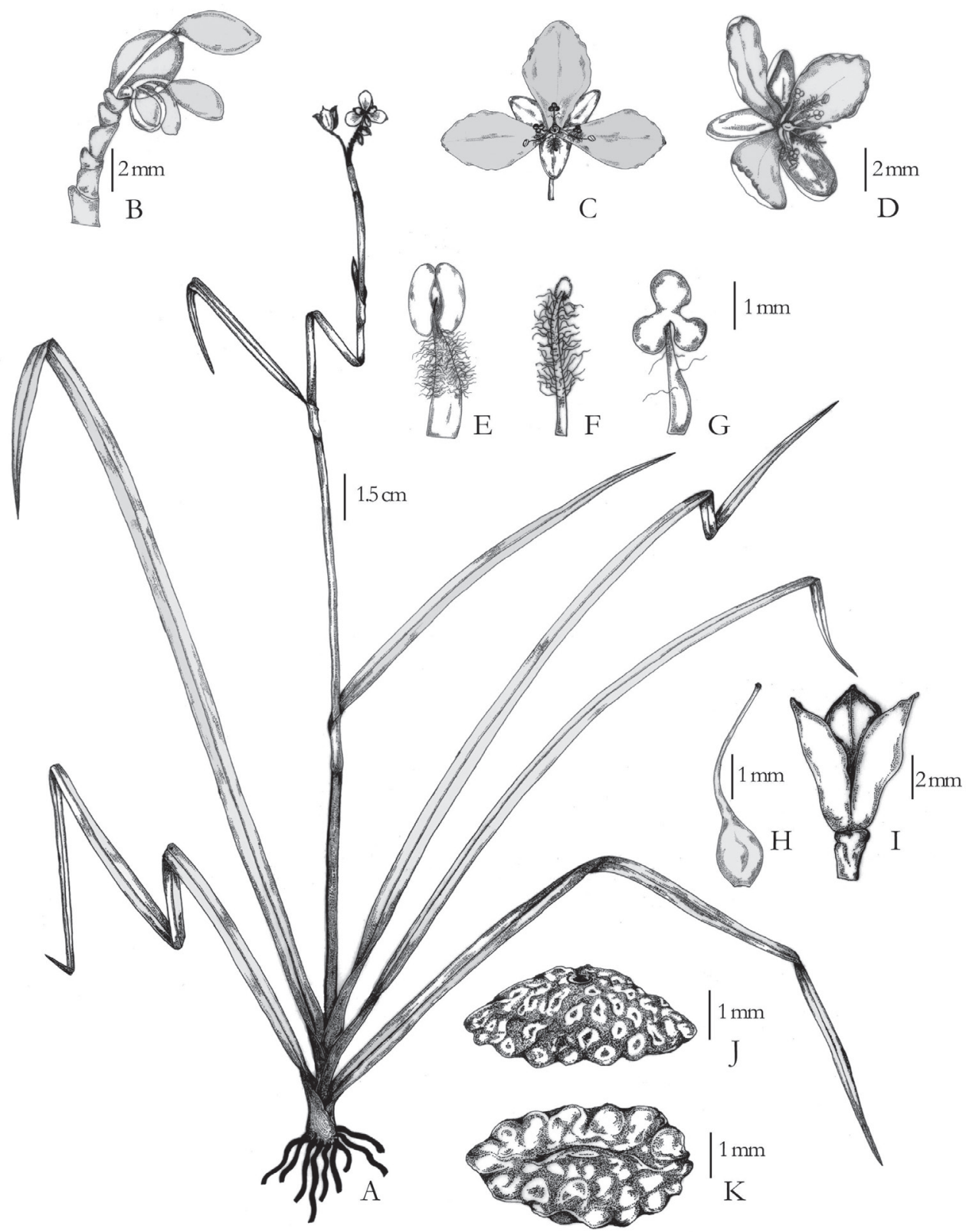

Figure 2. Murdannia saddlepeakensis A Habit B Inflorescence C Flower, ventral view D Flower, lateral view E Stamen F Rudimentary stamen G Staminode H Pistil I Capsule J Seed, lateral view K Seed, ventral view. All from $M V$ Ramana 0550. Drawn by Mayur Nandikar

have revealed that $M$. crocea subsp. crocea is known only from Myanmar, Tenasserim [Herb. Helfer 5497 (K!)]. No one has reported this species till from India after Helfer's collection. A key for the species of the genus Murdannia in Andaman and Nicobar 
Islands and closely related taxa of the new species is given below to facilitate identification (modified after Faden 2000).

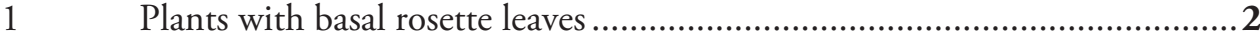

- Plants without basal rosette leaves ..............................................................5

2 Rosette leaves $0.4-0.8 \mathrm{~cm}$ wide; capsule subglobose; locule one seeded M. saddlepeakensis

- $\quad$ Rosette leaves (0.5-) 0.8-1.5 cm wide; capsule ovoid to ellipsoid; locule two

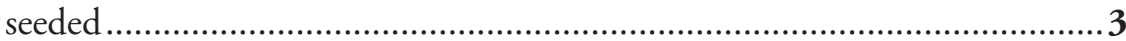

3 Flowering shoots terminal in the rosette; seeds ovoid to ellipsoid, $2.5-4 \times 2-$ $2.5 \mathrm{~mm}$, hilum linear. M. gigantea

- $\quad$ Flowering shoots lateral in the rosette; seeds ovoid to obovoid, 1.6-2 × 1.5 $\mathrm{mm}$, hilum linear to oblong ................................................................... 4

4 Pedicels 3-5 mm long; seeds 1.5-2 mm long; flowers 12-15 mm wide, opening after noon M. simplex

- $\quad$ Pedicels 2-3 mm long; seeds 1.4-1.8 mm long; flowers 9-12 mm wide, fading by noon M. loriformis

5 Leaves subtending inflorescence bract-like; capsule globose; locule one seeded

M. vaginata

- $\quad$ Leaves not subtending inflorescence bract-like; capsule ovoid to obovoid or elliptic; locule more than 2 seeded ............................................................6

6 Leaves linear-lanceolate to linear-oblong; seeds 2 per locule......M. nudiflora - Leaves lanceolate to ovate; seeds 3-7 per locule M. spirata

\section{Acknowledgements}

The work was undertaken as a part of the project titled "Quantitative Assessment and Mapping of plant resources of Andaman and Nicobar Islands" funded by DBT, Ministry of Science \& Technology, Government of India. MN thanks Dr. Robert B. Faden, Smithsonian Institution, Washington DC for his primary comments, Prof. S. R. Yadav and Manoj Lekhak, Department of Botany, Shivaji University, Kolhapur for critical going through the manuscript. Open access to this paper was supported by the Encyclopedia of Life (EOL) Open Access Support Project (EOASP).

\section{References}

Brückner G (1930) Commelinaceae. In: Engler HGA, Prantl KAE (Eds) Die natürlichen Pflanzenfamilien. ed. 2. Engelmann, Leipzig, 159-181.

Faden RB (2000) Commelinaceae. In: Dassanayake MD, Clayton W (Eds) A revised handbook to the flora of Ceylon. Oxford \& IBH Publishing, New Delhi, 140-171. 
Govaerts R, Faden RB (2004) World checklist of Commelinaceae. The Board of Trustees of the Royal Botanic Gardens, Kew. Published on the Internet; http://www.kew.org/wcsp/ accessed 07.02.2011; 14:03 GMT+05.30.

IUCN (2001) IUCN Red List categories and criteria. Version 3.1, Prepared by the IUCN Species Survival Commission. IUCN, Gland, Switzerland, and Cambridge, United Kingdom.

Joby P, Nisha P, Rameshan M, Augustine T, Rogimon PT, Unni KS (2011) Murdannia satheeshiana-a new species of Commelinaceae from Western Ghats, India. Phytotaxa 22: 41-46.

Karthikeyan S, Jain, SK, Nayar MP, Sanjappa M (1989) Florae Indicae enumeratio: monocotyledonae. Botanical Survey of India, Calcutta, 27-30.

Nampy S, Joby P (2003) Murdannia fadeniana Nampy \& Joby (Commelinaceae), a new species from India. Candollea 58: 79-82.

Nandikar MD, Gurav RV (2011) A new species of Murdannia Royle (Commelinaceae) from northernwestern Ghats of India. Taiwania 56(3): 227-230.

Nandikar MD, Gurav RV, Umesh D (2011) Rediscovery of Murdannia striatipetala (Commelinaceae) - a little known species from southern India with a note on its identity and distribution. Journal of Bombay Natural History Society 108(1): 67-68.

Pandey RP, Diwakar PG (2008) An integrated checklist flora of Andaman and Nicobar Islands, India. Journal of Economic \& Taxonomic Botany 32: 403-500.

Rao MKV (1986) A Preliminary report on the angiosperms of Andaman and Nicobar Islands. Journal of Economic \& Taxonomic Botany, 8: 107-184. 